tial evidence bearing on the theory that the Druids came from the south, while the British Celts came from the east; that they, or their representatives, were in Britain before the Celts-that is, in the Neolithic age or the age of the megalithic monuments; and that the Druids of the times of Cæsar and Pliny were priests or professors of a Celticised Iberic system. As evidence, the southern origin of the oak-mistletoe association would agree admirably with some syntactical peculiarities of British Celtic speech which are distinctly nonAryan, and have been traced southward through North African dialects to ancient Coptic.

\section{JohN Griffith.}

\section{FAGNANO'S MATHEMATICAL WORKS.}

Opere Matematiche del Marchese Giulio Carlo de' Toschi di Fagnano. Pubblicate sotto gli auspici della Società Italiana per il Progresso delle Scienze dai soci V. Volterra, G. Loria, D. Gambioli. Volume Primo. Pp. ix $+a-q+474$. Volume Secondo. Pp. xi +47 I. Volume Terzo. Pp. $x i+227+2$ plates. (Milano, Roma \& Napoli : Albrighi, Segati e C., I9I I and 1912.) Price 40 lire (complete in three volumes).

\section{IULIO CARLO DEI TOSCHI DI} FAGNANO was born in Senegal on September 26, I682, and died there on May 18 , 1766. In his boyhood he composed poetry; later on he was attracted to the study of philosophy and became a follower of Leibniz and Newton. At the age of fourteen he went to college at Rome, but his taste for mathematics only developed later, and he had to devote himself to its study without assistance out in Senegal. Although he became absorbed in his mathematical studies sometimes for days at a time, he also occupied himself with administrative work, and gave expert advice to the Pope Benedict XIV. regarding the safety of the cupola of St. Peter's at Rome. In return, the Pope promised to publish his "Mathematical Productions," but for some reason the promise was not fulfilled, and they were not published until I750.

The best-known original work of Fagnano is that referring to the rectification of curves. "Fagnano's Theorem," relating to certain properties of arcs of ellipses, has frequently figured in English text-books, and is now recognised as the starting-point from which sprang the modern theory of elliptic functions. That such was actually the case is confirmed in the preface to these volumes, where it is stated that the work of Euler and Jacobi was initiated by the examination of a presentation copy of Fagnano's works, received by the Berlin Academy of Sciences.

$$
\text { No. } 2257 \text {, VOL. 90] }
$$

This and other circumstances led the Italian Association for the Advancement of Science to undertake the publication, not only of Fagnano's "Mathematical Productions," but also of his unpublished writings and correspondence, the work being placed in the hands of Profs. Volterra, Gino Loria and Gambioli.

The first two volumes contain the "Produzioni," as originally published by Fagnano. The greater part of vol. i. is taken up with a treatise on the geometrical theory of proportion, which includes the whole of the propositions in Euclid's fifth book. In addition, we have papers on the solution of the cubic and biquadratic and on the mathematics of gambling, with special reference to lotto-a subject of considerable importance in Italy, where the Banca di lotto is a source of revenue to the State. The second volume contains a treatise on rectilinear triangles, and Fagnano's contributions to the study of analysis. These latter, unlike the former, consist of a series of short papers which perhaps constitute the most important of Fagnano's works. The third volume consists of work not included in Fagnano's opus magnum, namely, articles published after the appearance of the "Productions" in $175^{\circ}$, as well as correspondence. The collection of the material for this volume is due to Prof. Gambioli. A biography of Count Fagnano forms a fitting conclusion.

The series of volumes forms a useful addition to the archives of mathematical history. That the original work of this mathematician still opens up fields for investigation is shown by a recent paper on elliptic trammels and Fagnano points, contributed to The Mathematical Gazette for May and July, r9I I, by Mr. Percy J. Harding.

\section{G. H. B.}

\section{GEOLOGY IN THE SOUTHERN HEMISPHERE.}

(I) South African Geology. By Prof. E. H. L. Schwarz. Pp. 200. (London: Blackie and Son, Ltd., Igr2.) 3 s. 6d. net.

(2) Geology of New Zealand. By Dr. P. Marshall. Pp. viii +2 I8. (Wellington, N.Z. : J. Mackay, Government Printer, I9I2.)

(3) An Introduction to the Geology of New South Wales. By C. A. Süssmilch. Pp. xii $+\mathbf{I} 77$. (Sydney, N.S.W. : W. A. Gullick, Government Printer, 19II.) $5^{s}$.

7 HESE three books are written with an educational purpose, and are kept within the limits of size suitable for schools. They alike bear witness to the prominent place taken by geology in the outlook of settlers in the southern hemisphere. Where human history may be traced 